\title{
CHARACTERIZATION OF HISTORIC MORTAR SAMPLES AND PERIOD ANALYSIS: A CASE STUDY
}

\section{ECE ERDOGMUS ${ }^{1 *}$, MINE HAMAMCIOGLU TURAN, ${ }^{2}$ JOSHUA FREEDLAND ${ }^{3}$, AMANDA GAGGIOLI ${ }^{4}$, MICHAEL HOFF ${ }^{5}$}

\author{
${ }^{1}$ Professor, Durham School of Architectural Engineering and Construction (DSAEC) \\ University of Nebraska-Lincoln (UNL) \\ e-mail: eerdogmus2@unl.edu (*corresponding author) \\ ${ }^{2}$ Professor, Faculty of Architecture, \\ Izmir Institute of Technology (IZTECH) \\ e-mail: mineturan@iyte.edu.tr \\ ${ }^{3}$ Principal, Wiss, Janney, Elstner Associates, Inc. \\ email:jfeedlamd@wje.com \\ ${ }^{4}$ Graduate Student, Department of Classics, Stanford University \\ e-mail: gaggioli@stanford.edu \\ ${ }^{5}$ Professor, School of Art, Art History \& Design, University of Nebraska-Lincoln (UNL) \\ e-mail: mhoff1@unl.edu
}

Keywords: Lime mortar, Roman mortar, Byzantine mortar, rubble masonry, mortar characterization

\begin{abstract}
The Imperial Temple in Antiochia Ad Cragum is estimated to be first constructed at the end of $2^{\text {nd }}$ or start of $3^{\text {rd }}$ century, the time of the Severan dynasty. However, archaeological evidence also suggests that there were interventions during the Byzantine era, with burials over the temple platform, a wine press on the northern side, and walls constructed perpendicular to the temple on the southern side, use of which are unidentified. There is also a retaining wall in the back of the temple that holds the earth against erosion from the hill on the back, but it is curiously close to the Temple if built as part of original construction.

The goal of this study is to investigate the authors' hypotheses of a multi-phase use and to identify which elements found on the site may be contemporary to each other by comparing the composition of mortar samples collected from different areas, supplemented by a geoarchaeological investigation. Five samples of mortar from the various areas around the temple were collected and tested using three methods: X-ray diffraction (XRD), Scanning Electron Microscope (SEM), X-ray fluorescence (XRF) and thin section petrographic analyses. While all mortar samples include similar locally sourced hydrated lime and sand mixtures, three distinct construction styles are identified in the visual analysis of the building elements, the mortar analyses, and the geoarchaeological investigations. One sample from the walls of the wine press pool includes fibers. The unique interdisciplinary work utilizing both material analyses and geoarchaeology strengthens the conclusions that can be drawn from individual fields of study and provides more support for the hypotheses of the phased destruction and changing use of the monument.
\end{abstract}




\section{INTRODUCTION}

The Imperial Temple in Antiochia ad Cragum (near modern day Gazipaşa, Turkey) was found in a state of ruin, where the marble blocks fell onto and around the platform. An interdisciplinary team of archaeologists, engineers, and conservators have been working on assessing and evaluating this site since 2005. A pediment and Corinthian column capitals immediately suggested a Roman temple as the original architectural layout of the ruin; however, very little was known otherwise. During the course of excavation, the archaeologists on the team identified the temple's construction date to the end of the 2 nd or beginning of the 3rd century AD based on ceramic evidence. The temple is stated to be an imperial dedication, although it is not known to which emperor [1]. Authors believe that, while the original use of this structure was a Roman temple; based on the evidence found over the years of excavation, the building was repurposed in later years. This evidence includes graves found on the temple platform identified by human remains and jewelry fragments dating to the Byzantine era, a wine press as identified by Dodd [2] on the west side with a flat surface and a small vat, and on the east side, walls perpendicular to the temple with drainage holes at the bottom (Fig.2). In addition, there is a retaining wall on the north side of the temple against the hill above and foundation walls below the stairs at angles not normal to the temple.

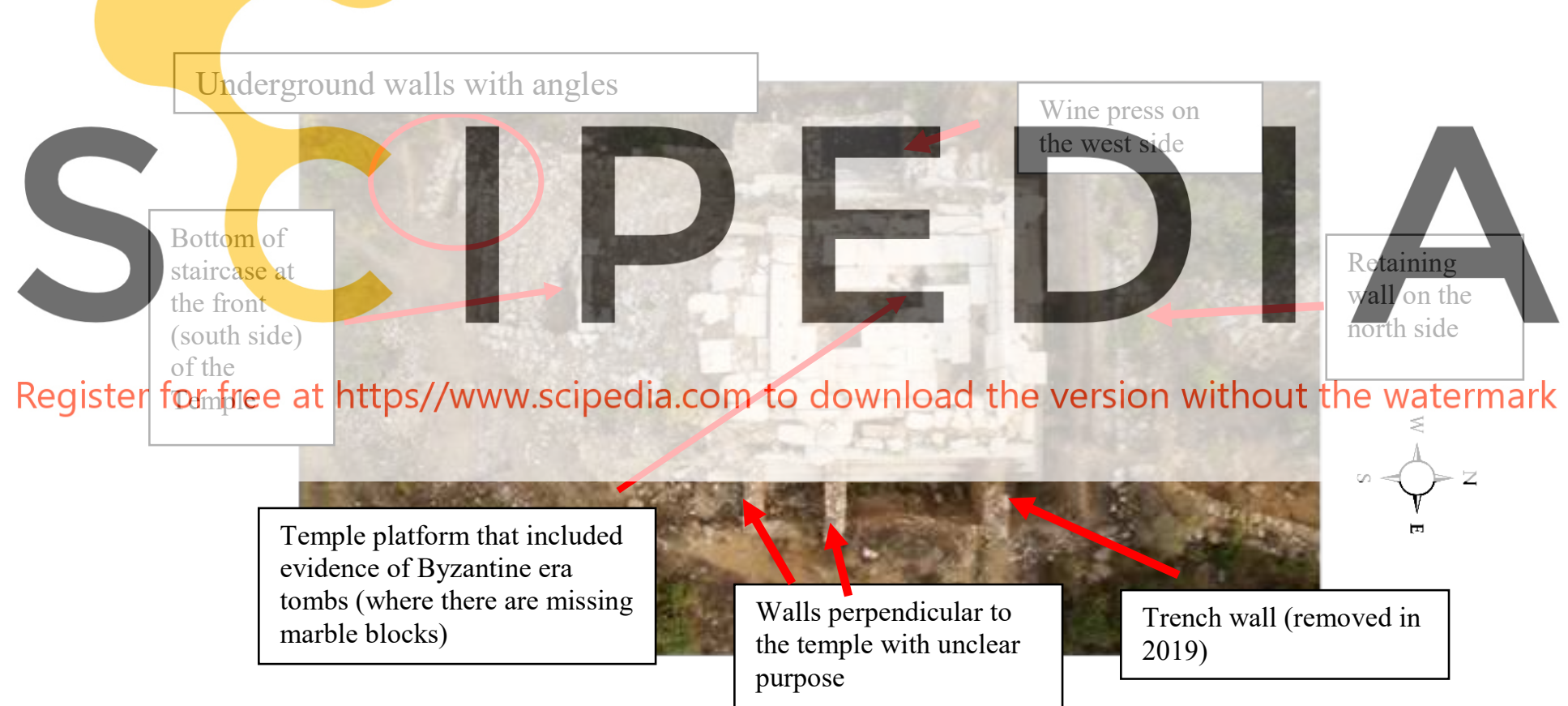

Figure 1. Aerial photo of the Temple platform and surroundings

The goal of this study is to investigate the authors' hypotheses of a multi-phase use and to identify which elements found on the site may be contemporary to each other by comparing the composition of mortar samples collected from different areas, supplemented by a geoarchaeological investigation. 
The mortar analysis compared five mortar samples collected from under the stairs, the wine press area, the walls on the east side, and the retaining wall. Future studies will also consider analysis of the angled walls under the foundation and walls behind and to the north of the retaining wall (Fig.2). The geoarchaeological investigation included in this paper entailed site measurements and stratigraphic investigations.

\section{ANALYSIS OF THE SITE AND HYPOTHESES FOR USE PHASES}

It is not known when this temple, or the Imperial temples in general, would have ceased operation, but it can be estimated that it probably occurred after the Theodosian Edicts of ca. 390 that essentially ended all non-Christian worship. Even after that, it is known that pagan activity continued for some time, until finally extinguished under Justinian (527-565). Religious activity had stopped at least by the time the wine press was constructed. The authors speculate that this stage of the building's life was after an initial collapse of the front facade of the structure, whether due to natural events (such as an earthquake) or on-purpose by the new non-pagan habitants.

\section{The foundation to the temple podium and the stairs are constructed with rubble stone and} mortar, and finished with dry set marble blocks. The columns, the cella walls, and the floor of the podium are constructed out of dry set marble blocks. There are remains of regular marble stones at the bottom of the mound (Fig. 1) that are identified as the remains of a marble staircase

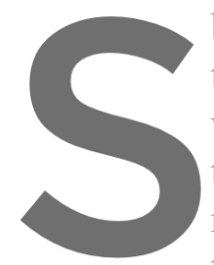
between the street leve temple (Fig. 1 and 2) tur wall is a single leaf con trying answer is whether the retaining wall is makes sense to build to the building and there are some decorated e
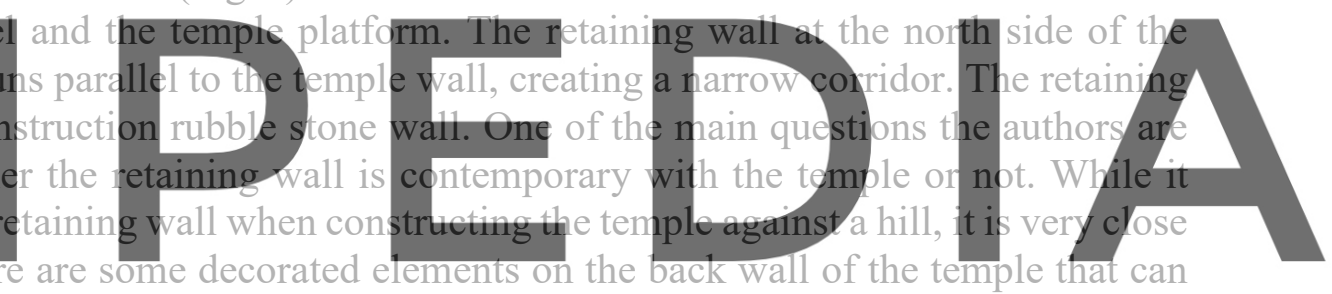
cause some speculation that it is a later addition. The two similarly constructed rubble walls

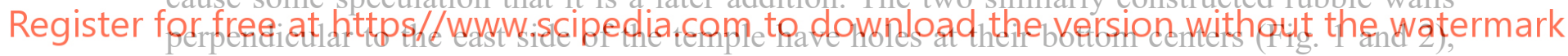
which suggest flow or drainage of fluids. Authors speculate that these walls belonged to the wine press period, because there is no architectural or structural reason for these walls to be contemporary with the temple.
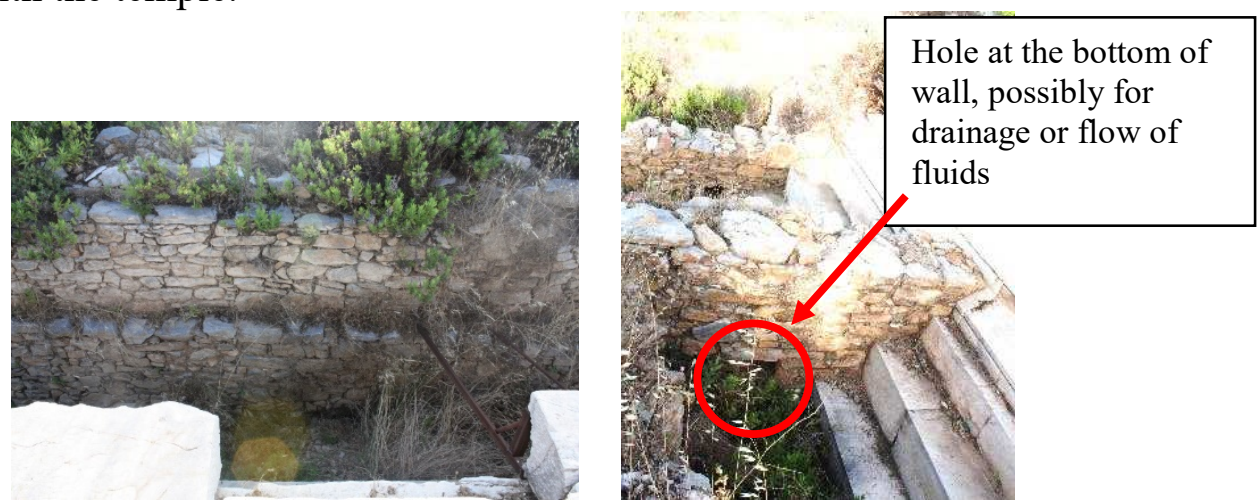

Figure 2. (a) The retaining wall on the north side, (b) One of the perpendicular walls with bottom hole on the east side 
Further, the workmanship of the retaining wall is slightly different from the eastern walls perpendicular to the temple, where the rubbles are relatively larger and the mortar joints between the stone is thinner. Nevertheless, all of the building stones appear to be from the region and have similar geological characteristics [3].

The wine press components identified on site include a treading floor and a collection vat (Fig. 3). The production process in the Antiquity involved several steps and several areas, which are identified at the Antiochia ad Cragum site. According to Dodd [2], regional archaeological discoveries and established history of the region permits the probable assumption that grape vines were located relatively close to the press in the surrounding fields and terraces. This would lower the transport costs as well as reducing loss of the prized first juices released by the grapes as they are transported. Harvested grapes were then brought to the press in baskets and gathered nearby for sorting, the removal of unwanted matter, and, depending on the type of wine produced, dehydration. Dodd notes "It is possible that the large disused temple floor above was used as a space to dry grapes on mats for the creation of raisin wine." Then the grape juice (must) was extracted either with static pressure under their own weight, but more likely for this location, by crushing underfoot on the treading floor. The juice then flows downward (the floor is slightly canted towards the vat on the west side) until it flows through a ceramic pipe (discovered on the site) and into the vat. The must then settled in the collection vat for filtration purposes. Any suspended settleable sediment (remaining heavy solids and residues) was bedded in the base depression of the collection vat This process could be completed, with additives, in as fast as three days in antiquity. After
this, fermentation took place, but Dodd states that it is difficult to interpret wherc and in what
form did fermentation occur at this site. Two theories are offered by Dodd, with more
plausibility of in-vat fermentation and wine production in limited amounts. Reader is referred
to Dodd [2] for a more detailed study of the wine workshop at Antiochia ad Cragum.

Register for free at https//wrww.seffedia.com to download the version without the watermark

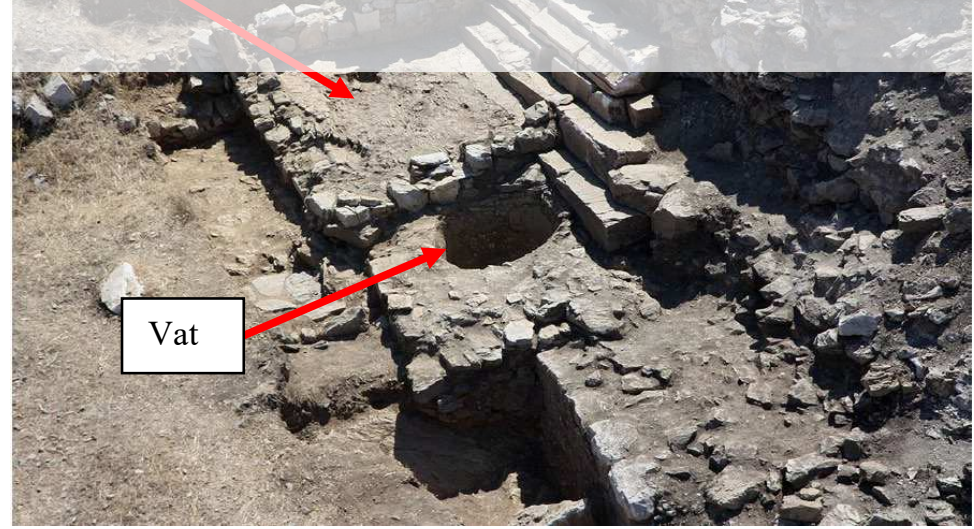

Figure 3. Antiochia ad Cragum wine press (source: Dodd, 2020)

In addition to Dodd's theories, the authors of this paper hypothesize that the eastern area with perpendicular walls to the temple may be used either for washing of the grapes or for additional areas of fermentation (Fig. 2). Areas that necessitate human labor were likely 
organized such that they were partially protected from sun light, which is one of the reasons why authors speculate a later collapse of the cella walls than the front facade. A semi or fully erect cella could provide the shaded and cooler work space needed; but a semi-erect cella is more likely as it would be difficult to transfer the grapes from the washing area to drying to smashing with all walls erect. Dodd performed a shadowing study for different times of day, that also suggests the western location of the fermentation pool was intentional and in shade most of the day. The stairs of the temple likely provided ease in accessing the workshop as well. Figure 4 provides a potential work flow for the workshop.

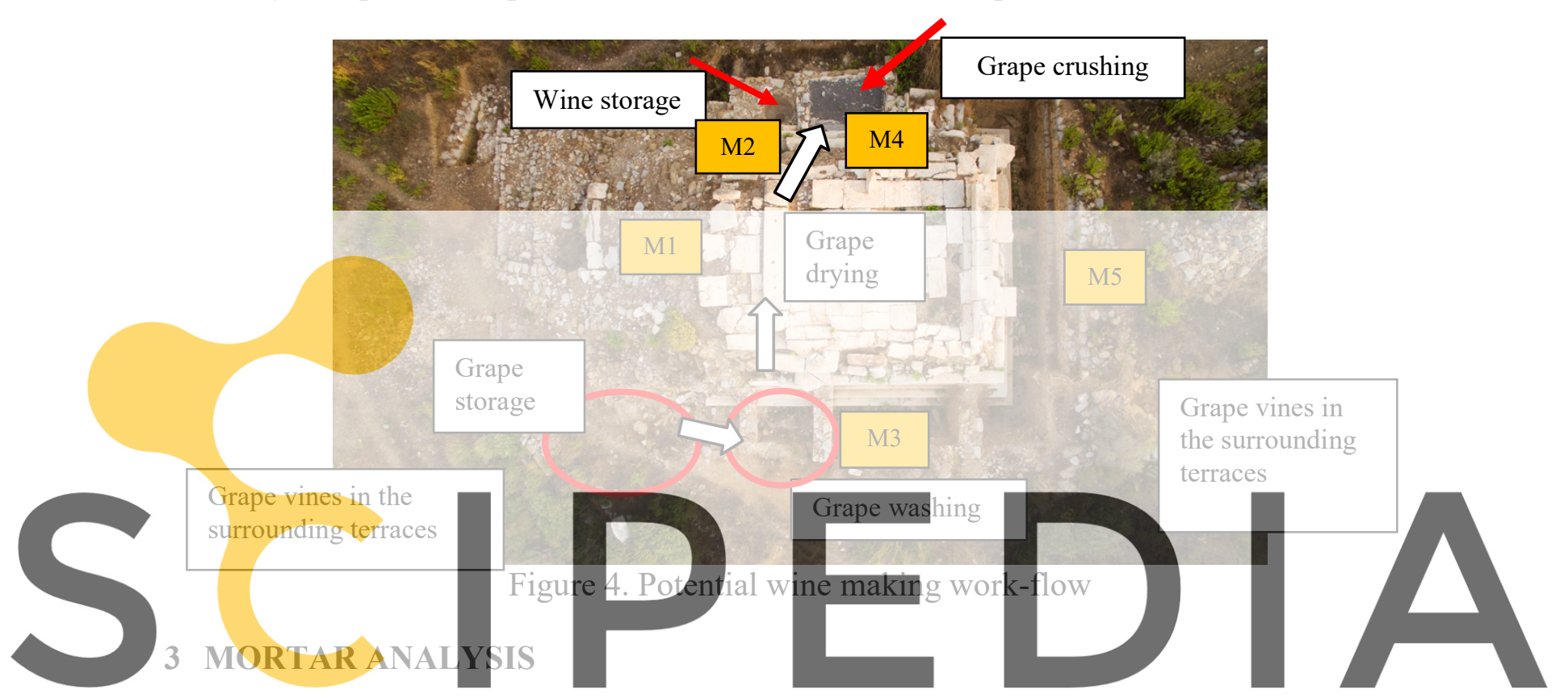

Five mortar samples are collected from various areas on the site. In this section, sample

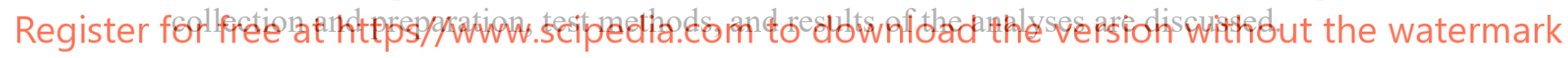

\subsection{Sample Collection}

Five mortar samples were collected in 2018 from the areas shown in Figure 4 as M1 through M5, and described in Table 1. The samples (Fig. 5) are identified as soft and friable (i.e. exhibited low cohesive strength).

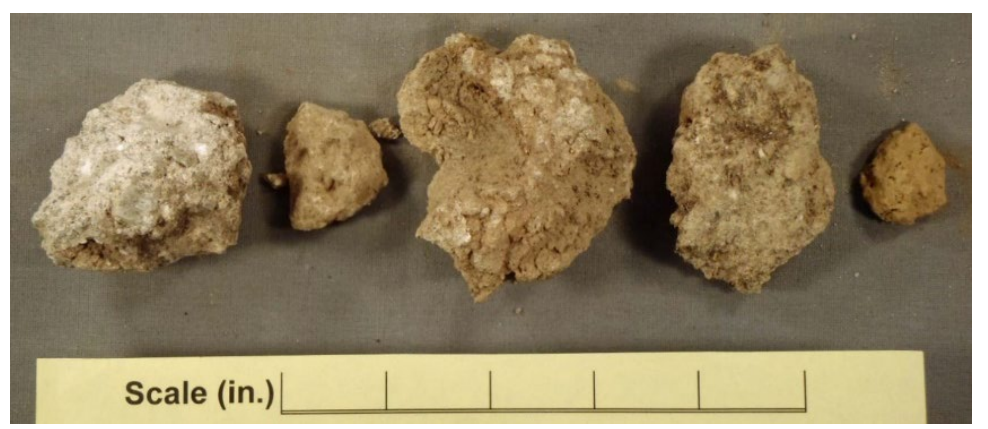

Figure 5. The as-received appearance of the five mortar samples are pictured from Sample M1 (left) to Sample M5 (right). 
E. Erdogmus, M. Turan, J. Freedland, A. Gaggioli, and M.Hoff

Table 1. Sample Descriptions and Compositions as Determined by Analyses

\begin{tabular}{|c|c|c|c|c|}
\hline $\begin{array}{c}\text { Sample } \\
\text { ID }\end{array}$ & $\begin{array}{c}\text { Sample } \\
\text { Type }\end{array}$ & Sample Dimensions & Extraction Location & Composition \\
\hline M1 & Mortar & Irregular fragment & Under the front steps platform & Hydrated lime-sand mortar \\
\hline M2 & Mortar & Irregular fragment & Inside the wine press/hole & Hydrated lime-sand mortar \\
\hline M3 & Mortar & Irregular fragment & $\begin{array}{c}\text { From wall constructed later, } \\
\text { oriented perpendicular to the } \\
\text { Temple wall }\end{array}$ & Hydrated lime-sand mortar \\
\hline M4 & Plaster & Irregular fragment & Plaster from the wine press wall & Hydrated lime-sand mortar \\
\hline M5 & Mortar & Irregular fragment & $\begin{array}{r}\text { Toward the bottom of the back } \\
\text { retaining wall }\end{array}$ & Hydrated lime-sand mortar \\
\hline
\end{tabular}

\subsection{Mortar Analysis Methods}

Three methods were employed to analyze the mortars: XRD, SEM and thin section petrographic analysis. Mineralogical compositions of the samples were determined by X-ray diffraction (XRD) analysis performed using a Philips X'Pert Pro X-ray diffractometer operating at $45 \mathrm{kV}$ and $40 \mathrm{~mA}$, using $\mathrm{CuK} \alpha$ radiation in the 5-80 range with a scan speed of 1.5 per min. Chemical compositions of all samples were determined by Philips XL30-SFEG Scanning Electron Microscope (SEM). Optical microscopy was performed on prepared thin sections at magnifications ranging from 50X to 630X. Examinations were conducted in accordance with ASTM C856 [4], Standard Practice for Petrographic Examination of Hardened Concrete, which can be applied to mortar. Due to the friable nature of the mortar fragments, they were
impregnated with epoxy prior to sample preparation. After the epaxy hardened, a cross-
sectional surface was saw-cut through the interior of each epoxy-impregnated fragment. One
of the sawed surfaces was used to prepare a thin section. The companion surface was lapped
using discs of progressively finer abrasives to achieve a fine, matte surface suitab/e for
examination with a stereomictoscope. As enough relevant information is captured fron these
assessments, no wet chemical analysis was performed.

Register for free at https//www.scipedia.com to download the version without the watermark 3.3. Mortar Analysis Results

The analysis showed that all samples are hydrated lime-sand mixtures and no evidence for hydraulic lime was found. The paste ranged in color from buff to tan to light tan between the four samples (M1 through M4) as shown in Figure 5.

SEM analyses show that, in some portions of the mortar, there are layers of clay minerals (Fig. 6). Further, the binder was amorphous in texture mainly composed of calcium carbonate $\left(\mathrm{CaCO}_{3}\right)($ Fig. $7 \mathrm{c})$. Calcium carbonate is likely from the calcite rock that was used to produce the lime. Muscovite fragments and quartz are also observed throughout the mortar (Fig. 8). These two relatively less observed materials may be present in the calcite rocks used in the lime production. Samples M1, M2, M3, and M4 all contain hydrated lime lumps that were generally free of impurities (Figs. 7-9). The lime lumps were typically smaller than $0.5 \mathrm{~mm}$ but lumps with maximum sizes of approximately $3 \mathrm{~mm}$ to $5 \mathrm{~mm}$ and larger are observed as well. Shrinkage cracks, typical for lime-based mortars, were also observed during the petrographic analyses (Fig. 8). M1 has a relatively richer calcite amount as revealed in its whitish color in thin section analyses (Figs. 7 and 9) and in the form of relatively higher calcite peaks (exceeding 
200 counts/s) in the XRD analysis. Therefore, in the original rubble stone foundation walls of the temple, lime content was likely higher. This original mortar also has the least amount of voids, indicated with blue dyed epoxy in Figure 9.
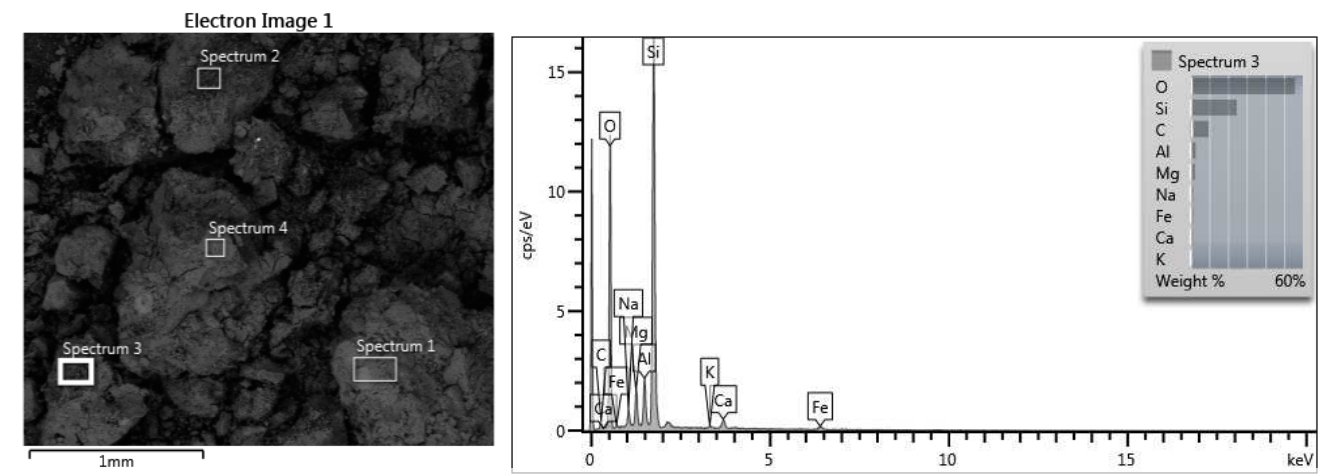

Figure 6. SEM results for sample M1
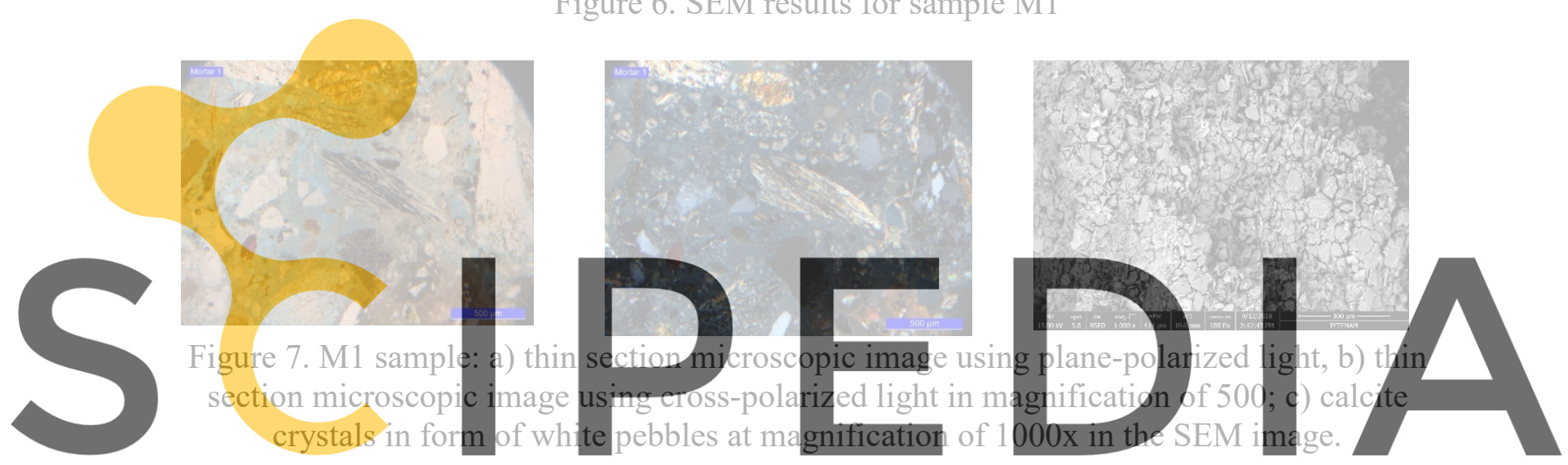

Register for free at https//www.scipedia.com to download the version without the watermark

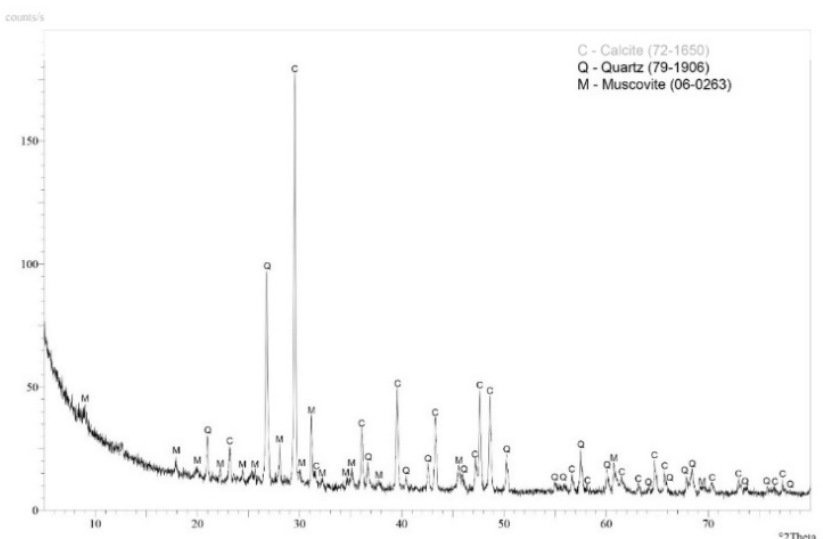

(a)

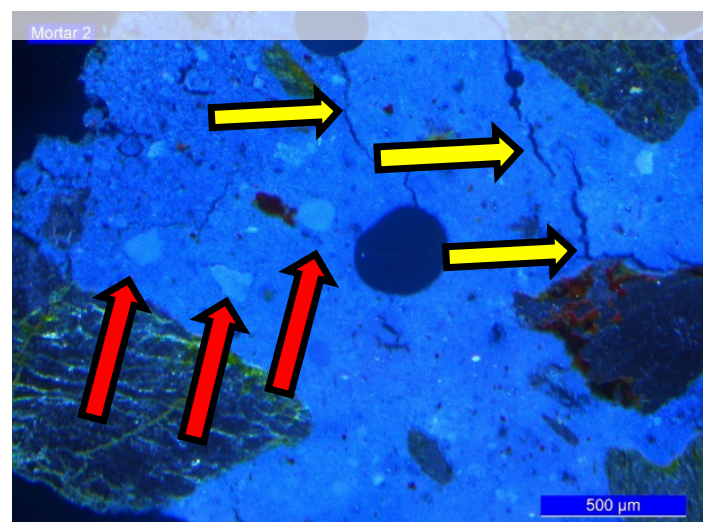

(b)

Figure 8. (a) XRD pattern of sample M2; (b) Hydrated lime lumps (red arrows) and shrinkage cracks (yellow arrows), pictured in thin section of sample M2 using oblique reflected light. 
The voids that are irregularly-shaped (indicated with blue in Fig. 9) likely contained free water, when the mortar was installed. The volume of voids varies between the examined samples. Voids were commonly lined with secondary calcite crystals, indicating moisture migration through the samples over time. This migration has given way to deterioration of mortars and plasters, in relation with overall weathering, accumulation of rain water around the temple and the salts that were carried from the ground.
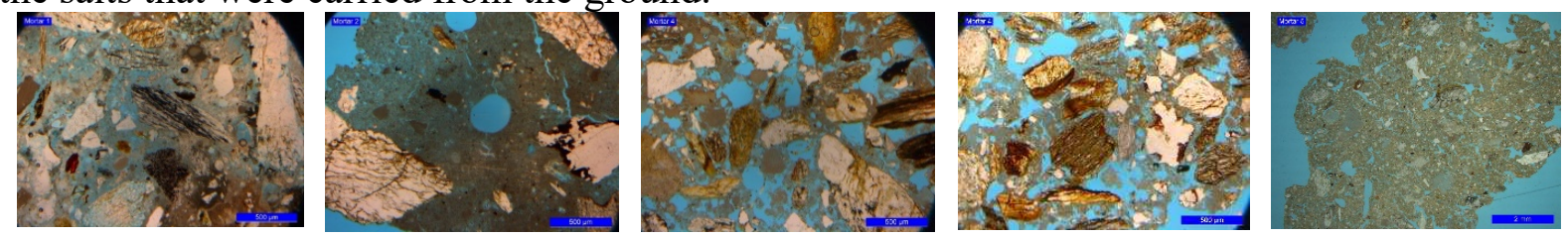

Figure 9. Comparison of thin sections using plane-polarized light in magnification of 100 and 500; M1 through M5, from left to right.

An abundant amount of void space is observed in samples M3 and M4, which are mortar and plaster samples from the Byzantine walls, respectively. The difference between void volumes may be related to placement techniques in addition to variations in initial water-to-solids content of the freshly mixed material. M2 has relatively more binder (Fig. 9). The sand in the samples consists primarily of calcite, mica, quartz, quartzite, and metamorphic rock fragments (either phyllite or schist), as revealed in both the thin section and XRD analyses (Fig. 7 and 8). The maximum-sized sand particles range from approximately $4 \mathrm{~mm}$ to $8 \mathrm{~mm}$. The sand particles

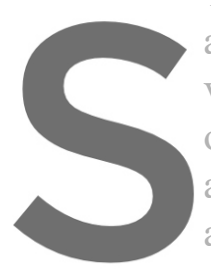
are sub-angular to roun volume of sand is obser other four samples. Preser achieving a fine mortar aample M4. In the Byza within ell graded and
tween the sampl
the press. Cellu
era, plasters with uniformly distri
es with fewer f
d less sand ma
lose fibers are
h ceiluiose rein to reduce shrinkage cracks and improve tensile strength [5-6].

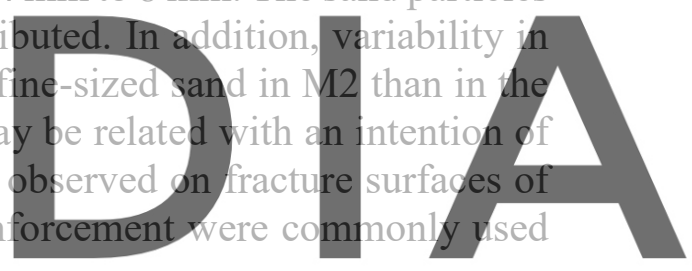

Register for free at https//www scipedia.6om to download the version without the watermark (Figs. 9 and 10), where the maximum-sized sand particle is typically less than $2 \mathrm{~mm}$, much finer than the other four examined samples. Additionally, sample M5 contains a larger volume of very fine-grained sand, including micas, quartz, and calcite, dispersed throughout the paste as compared to the other samples. The paste in sample M5 is brown in color (Fig. 9), extremely soft, and porous, indicating that the lime amount is relatively lower. It contains irregularlyshaped water voids and shrinkage cracks. Hydrated lime lumps were observed with lumps typically much smaller than $0.5 \mathrm{~mm}$ as compared to the other four samples, although larger lumps are present (Fig. 10). Some sand particles were embedded in hydrated lime lumps. This difference is legible in the XRD graph with weaker (lower than 150 counts/s) peaks for calcite and stronger peaks (exceeding 200 counts/s) for quartz (Fig. 10). Again, in the XRD, a strong peak for clinochrysotile, which is not detected in the other samples, is observed. This mineral, which is a type of serpentine, is known to be present in Antalya region [7]. When all these differences in mortar composition are evaluated together with the difference in the workmanship of the wall, it may be concluded that the retaining wall was constructed at a different time, or at least using a different technique, compared to the temple platform, wine press, and the east side walls. 

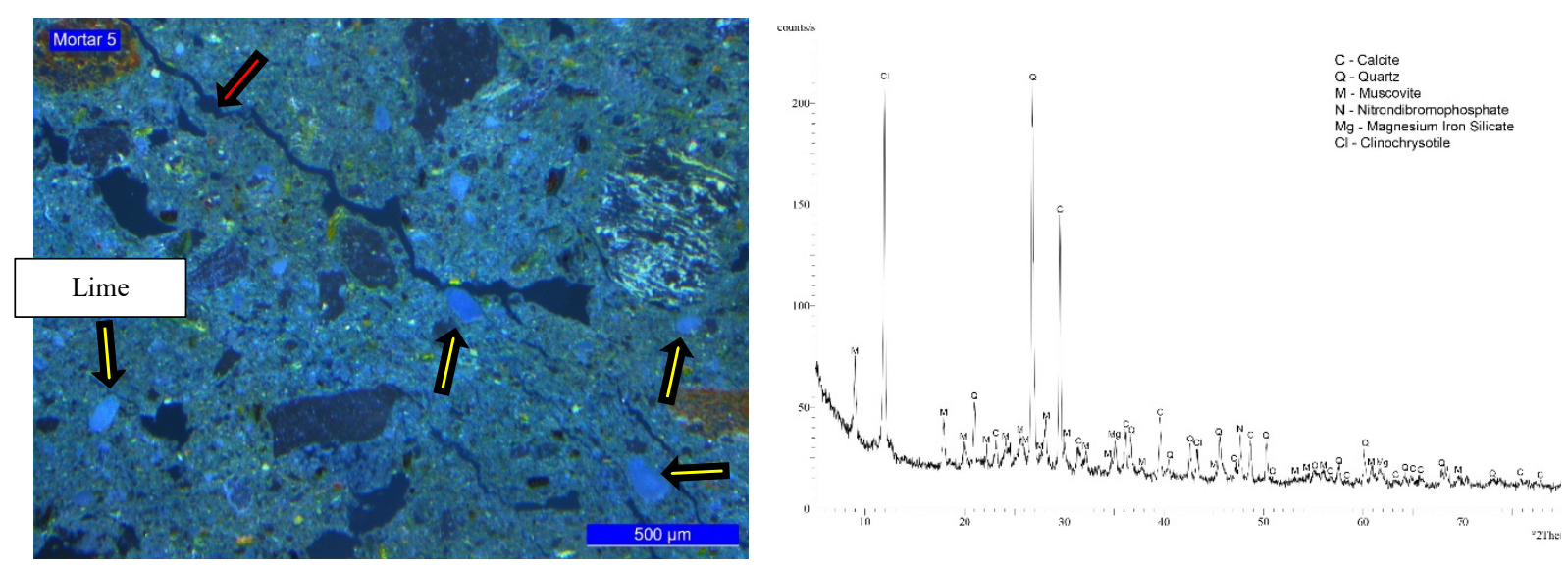

Figure 10. Sample M5 pictured using oblique reflected light (left), XRD pattern of M5 (right).

\section{GEOARCHEOLOGICAL INVESTIGATIONS}

Geoarchaeology is an interdisciplinary discipline, which combines subjects of earth sciences in order to inform interpretations of archaeological excavations and/or explore geological aspects of the human past [8]. The geoarchaeological investigation of the temple at Antiochia ad Cragum provides further information on associations between phases of construction, destruction, reconstruction, and cultural activities in particular phases of identified

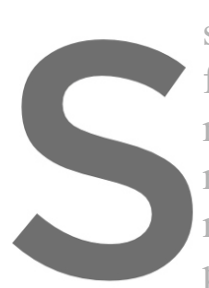
stratigraphic levels. D for soil micromorphologi material remains of the micromorphology is the microscopic level. The technique is employed processes and paleoenvironmental changes, an
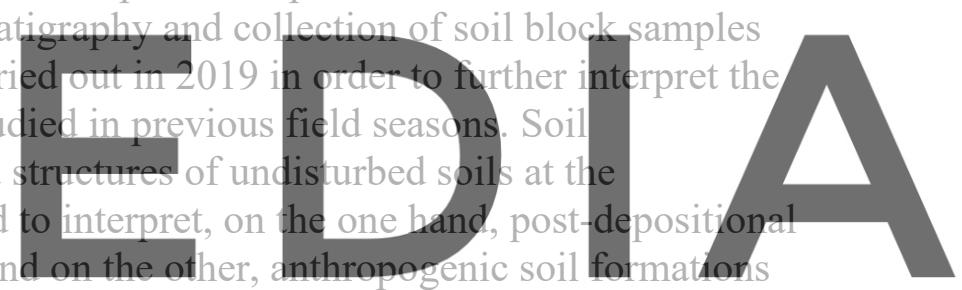
and disturbances, land management, and social uses and structuring of space [9].

Register for free at https//www.scipedia.com to download the version without the watermark The geoarchaeological investigation of the temple included the fieldwork recording and collection of soil block samples, and the micromorphological analysis of the soils collected. The northwest corner, northeast corner, and north end of the temple (Fig. 1) were selected for documentation and sampling, since each of these areas preserved an undisturbed stratigraphic sequence from the limestone bedrock below the temple's foundation up to the modern topsoil. A continuous set of soil blocks from three key stratigraphic areas were sampled in the baulks on the exterior sides of the temple. These included one sample below the foundation level of the structures, two at the occupational level of the structures, and one just above the occupational level of the foundation. The documentation involved recording major changes in the stratigraphy on the exterior of the temple in each of the areas and classifying the soil texture for each identified stratigraphic unit. These classifications will be refined during the soil micromorphological analyses. This requires the use of a petrographic microscope and Fourier Transform Infrared Spectroscopy (FTIR) to analyze microfacies, microfeatures, and elemental compositions. These stages of analysis will be carried out in the future using the protocols outlined primarily in Stoops [10] as well as the methods outlined in related literature [11-13]. 
From on-site geoarchaeological recording and analysis in the temple area, it is clear that Temple foundation sits almost directly on limestone bedrock. The various accumulations of colluvium in the stratigraphic sequences of the northwestern corner, northeastern corner, and north end of the temple are attributed to the temple's geological setting on a steep hillslope with the hill inclining to the north. In each of the three study areas, colluvium inclines in a direction parallel to the hillslope and demonstrates its movement from north to south. Above layers of colluvium, there is an accumulation of boulders and mortar in a layer ranging from approximately $20-50 \mathrm{~cm}$ in both the northwestern and northeastern corners of the temple. This layer is interpreted to be building debris from a destruction event. The boulders and mortar are deposited on a slope declining away from the temple and also in a downslope direction. The 40-50 cm accumulation of colluvium underneath the level of building debris in the northwestern corner demonstrates that the building's function as a temple in this area discontinued prior to its larger destruction in a later period, since the colluvium accumulated gradually whereas the building debris appears to have occurred more suddenly. The stratigraphy in the northern end of the temple follows a similar sequence in terms of the accumulation of colluvium above the foundation level, but the destruction level of the temple is not preserved in this area. Furthermore, the construction of a large terrace wall at the northern end and running the length of the temple reflects human efforts to minimize or stop the downslope movement of soils and materials onto the temple. The construction date of the terrace is unknown but given that the foundations of the temple and terrace are at the same stratigraphic level it i temple at the time of foundations in the nort anthropogenic activiti anthropogenic debris drain for moving and

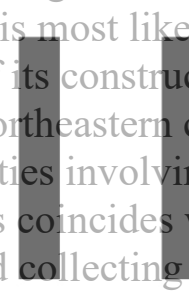
cely that this terr
uction. The sedi
corner is interp
ing the dumping
s with the conve
g waters flowing mentary seques
reted to be the
of waste mate
sion of the east
downslope in

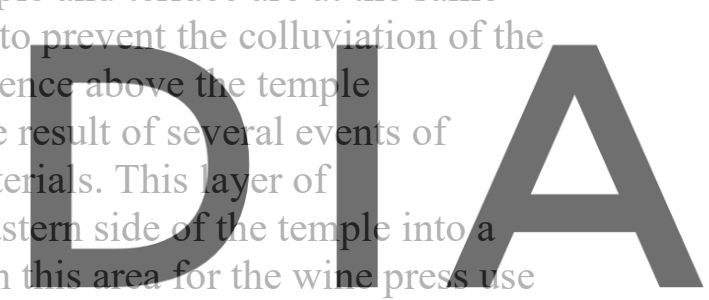

stage of the structure. The levels of colluvium and boulders in the northeastern corner

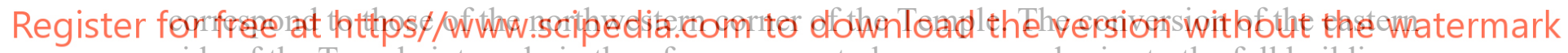
side of the Temple into a drain therefore appears to have occurred prior to the full building destruction event associated with the stratigraphic layer of large boulders.

Even though the soil micromorphological analyses are still being carried out, a number of preliminary interpretations about the sequencing of environmental and cultural events in the area of the temple can be made from the geoarchaeological investigation. Given the stratigraphic associations of the temple construction, destruction, colluviation, and anthropogenic activities in the temple area, it is likely that the social function of the temple changed prior to its full destruction as revealed by large boulders and mortar falling and deposited in a direction falling away from the temple. Prior to this destruction, the eastern part of the temple could have been used as a drain constructed for moving and collecting waters flowing downslope for use as part of the wine press, as demonstrated by accumulations of anthropogenic debris underneath layers of colluvium and architectural debris. The northwestern corner on the other hand went into disuse prior to the temple's larger destruction event as revealed by accumulations of hillslope colluvium underneath the layer of architectural debris. 


\section{CONCLUSIONS}

Three distinct construction styles are identified in the visual analysis of the building elements, the mortar analyses, and the geoarchaeological investigations: 1) A rubble core finished with cut stone blocks at the temple foundation (Sample M1). 2) Mortared rubble of small and medium sizes with thicker joints at the wine press installation (Samples M2, M3, and M4). 3) Mortared rubble of medium sizes put tightly together with minimum mortar thickness at the rear retaining wall (Sample M5)

While all of the mortar samples contain locally available lime and sand, their composition and characteristics slightly vary. Aggregates in the mortar of the retaining wall are finer and the amount of lime is lower. The mortar and plaster from the trampling and fermentation spaces contain an abundant volume of void space suggesting that the initial water to solid content was relatively high. Presence of less sand and more binder in the mortars of the press indicate a desire for better mechanical strength, and use of fibers on the walls of the pool walls indicate an attempt for better water resistance and durability. The findings differed slightly from the initially hypothesized use phases of the site. Samples M1 and M5 were expected to be similar and belong to the initial Pagan temple use-phase, and Sample M2, M3, and M4 were expected to belong to the later (wine press) use phase. However, sample M5 obtained from the retaining wall displayed more differences than the other four. When the differences in mortar composition of sample M5 are evaluated together with the difference in the workmanship of the wall, it could be concluded that the retaining wall was constructed at a different time compared to the temple platform, wine press, and the east side walls. However, because the foundations of the temple and terrace are at the same stratigraphic level and it is common construction practice to build a retaining wall when a structure is constructed on a hill on an excavated site, it is most likely that this terrace was built to prevent the colluviation of the temple at the time of its construction. As such, the differences are likely the result of a less considerate workmanship, given the wall's purpose and its location away from the eyes of the public. The other main research question was the purpose and construction time of the walls perpendicular to the temple on the east side. The similar material composition of these walls to those from the wine press elements on the west side and the drainage holes suggest a function related to washing the grapes or drainage of other fluids. The anthropogenic debris found in geoarchaeological investigations supports this theory, while lack of water-proof plaster in the mortar samples from the area challenges it. However, given the fact that the authors can find no other architectural and structural reasons for the construction of these walls, the governing hypothesis related to these walls remains to be a function related to the wine press installation.

The study contributes to the knowledge of mortars, plasters, and construction methods from the early Roman and Byzantine eras in Anatolia. The unique interdisciplinary work utilizing both material analyses and geoarchaeology strengthens the conclusions that can be drawn for either study alone and provides more support for the hypotheses of the phased destruction and changing use of the monument. 


\section{ACKNOWLEDGEMENTS}

The funding for this work is provided from the National Science Foundation (NSF) award \# 1559540. The opinions are those of the authors and not the NSF. We would like to thank Izmir Institute of Technology, Center for Materials Research for SEM and XRD analysis. We are thankful to Prof. Dr. Alper Baba, specialist Dr. Kerem Serifaki and Res. Assist. F. Sezgi Mamakli from IYTE for their contributions.

\section{REFERENCES}

[1] Erdogmus, Ece, Joshua Freeland, Michael Schuller, Mine Turan, Rhys Townsend, and Michael Hoff. 2019. "Preventive Conservation Efforts and a Preliminary Preservation Management Plan for the Roman Temple at Antioch Ad Cragum." Proceedings of the 13th North American Masonry Conference, pp. 222-226, June 2019, Salt Lake City.

[2] Dodd, E. (2020). Roman and Late Antique Wine Production in Eastern Mediterranean. Archaeopress Publishing Ltd., ISBN 978-1-78969-403-1 (2020).

[3] Chamber of Geology Engineers, 2019. Antalya İli Genel Jeolojisi (General Geology of Antalya Province), https://jeolojimuhendisleri.net/antalya-ili-genel-jeolojisi-il-il-geneljeoloji/, accessed: 7 February 2019.

[4] ASTM C856, Standard Practice for Petrographic Examination of Hardened Concrete

[5] T. Ashour, A. Derbala. Shrinkage of natural plaster materials for straw bale buildings affected by reinforcement fibres and drying, Agric Eng Int CIGR J, 12 (1) (2010), pp. 55-62

[6] M.F. Drdácký, M.J. Válek, P.P. Procházka, P. Bartos, C. Groot, J.J. Hughes (Eds.), Historic mortars: characteristics and tests, RILEM Publications, France (1999), p. 261

[7] Yalcin, H., Bozkaya, O., Yilmaz, C. 2015. Tekirova (Antalya) Ofiyolit Napı Kayaçlarının Alterasyon Mineralojisi ve Jeokimyası (Alteration Mineralogy and Geochemistry of the rocks from Tekirova (Antalya) Ophiolite Nappe), Türkiye Jeoloji Bülteni (Geological Bulletin of Turkey), V. 58, No: 1. http://dergipark.gov.tr/download/article-file/284508

[8] Ghilardi, M., and S. Desruelles. 2009. Geoarchaeology: Where Human, Social and Earth Sciences with Technology.

[9] Karkanas, P., and P. Goldberg. 2017. Encyclopedia of Geoarchaeology. Encyclopedia of Earth Sciences Series. Springer Netherlands.

[10] Stoops, G. 2003. Guidelines for Analysis and Description of Soil and Regolith Thin Sections.

[11] Bullock, P. 1985. Handbook for Soil Thin Section Description. Albrighton: Waine Research Publications.

[12] Courty, M.A. 1989. Soils and Micromorphology in Archaeology. Cambridge: Cambridge University Press.

[13] Macphail, R.I., and P. Goldberg. 2018. Applied Soils and Micromorphology in Archaeology. Cambridge University Press. 